\title{
The Development of Obesity in Genetically Diabetic-Obese (db/db) Mice Pair-fed with Lean Siblings
}

\author{
The Importance of Thermoregulatory Thermogenesis \\ P. Trayhurn and L. Fuller \\ Dunn Nutrition Laboratory, University of Cambridge and Medical Research Council, Cambridge, England
}

\begin{abstract}
Summary. The importance of reduced thermoregulatory thermogenesis as a mechanism for the high metabolic efficiency of the diabetic-obese $(\mathrm{db} / \mathrm{db})$ mouse has been investigated. Young $\mathrm{db} / \mathrm{db}$ mutants were pair-fed to the ad libitum food intake of lean siblings for two weeks at two different environmental temperatures, 23 and $33^{\circ} \mathrm{C}$. At $23^{\circ} \mathrm{C}$, a temperature at which there is a substantial demand for thermoregulatory thermogenesis, the diabetic-obese animals deposited $51 \%$ more total energy and $75 \%$ more fat than the lean mice. At $33^{\circ} \mathrm{C}$ (thermoneutrality) where there is no requirement for thermoregulatory heat, the mutants deposited $25 \%$ more fat than lean animals, but there was no significant difference in the total energy gain of the two groups. Pair-feeding resulted in a reduced protein deposition at both temperatures in the diabetic-obese animals compared to the lean. It is concluded that the high metabolic efficiency of the diabetic-obese mutant, like that of the obese (ob/ob) mouse, is caused by a low energy expenditure on thermoregulatory thermogenesis.
\end{abstract}

Key words: Obesity, diabetes, mouse, thermoregulation, thermogenesis, pair-feeding, energy, fat, protein.

Since its discovery some 15 years ago [13] the diabetic-obese $(\mathrm{db} / \mathrm{db})$ mouse has been increasingly used in experimental studies on diabetes and obesity $[2,4,11]$. These disorders in this animal result from a mutation which is recessively inherited. Hyperinsulinaemia is detectable in $\mathrm{db} / \mathrm{db}$ mice from 10 days of age [6] and an increased body fat content has been reported at 12 days [14]. Obesity as such is not apparent visually, however, until the animals are aged approximately 4 weeks. Recent work has indicated that obesity in the $\mathrm{db} / \mathrm{db}$ mouse is the result of two distinct factors - hyperphagia and an elevated metabolic efficiency $[4,7]$. The high efficiency has been demonstrated in studies where young diabeticobese mice were pair-fed to the ad libitum food intake of lean siblings $[4,7]$. The presence of both an elevated efficiency and hyperphagia in obesity has also been recorded in other commonly studied obese mutants, such as the obese (ob/ob) mouse $[1,3,9,18]$ and the fatty (fa/fa) rat [24].

In the present communication we report the results of pair-feeding experiments on the $d b / d b$ mouse which were conducted at two different environmental temperatures; $23^{\circ} \mathrm{C}$, a temperature where there is a substantial demand for thermoregulatory thermogenesis and $33^{\circ} \mathrm{C}$ (thermoneutrality) where there is no requirement for thermoregulatory heat. The aim of the study was to determine whether the low energy expenditure of the $\mathrm{db} / \mathrm{db}$ mouse, which is the underlying reason for its high efficiency, is due to reduced thermoregulatory thermogenesis. This is the explanation for the high efficiency of the ob/ob mouse $[18,21,22]$ and measurements of body temperature $[20,23]$, and metabolic rate [20] have suggested that a similar mechanism may also operate in the $\mathrm{db} / \mathrm{db}$ mutant. The diabetic mouse maintains a low body temperature, and its resting metabolic rate (per animal) at temperatures below the thermoneutral zone is lower than in normal mice, while at thermoneutrality there is no difference [20].

\section{Materials and Methods}

\section{Animals}

The mice used in these experiments were females from a colony established in our laboratory from breeding stock obtained in 1977 from the Jackson Laboratory, Bar Harbor, Maine, USA. The db gene was on a C57BL/ks background in repulsion to the misty coat gene $(\mathrm{m})$. Animals homozygous for diabetes-obesity were obese 
and black, heterozygotes were thin and black, while homozygous normal animals were thin and grey.

The $\mathrm{db} / \mathrm{db}$ mice were bred from heterozygotes, and were weaned at 21 days of age. The colony was housed in a temperature controlled room $\left(23 \pm 1^{\circ} \mathrm{C}\right)$, with a $12 \mathrm{~h}$ light/12 h dark cycle, the light period operating from $0800-2000 \mathrm{~h}$.

\section{Pair-feeding}

Mice were selected at an age of 3.5 weeks. At this time the obesity of the mutants was just detectable visually, and the body weight of both the mutants and the controls was between 8.0 and $10.5 \mathrm{~g}$. The control lean mice were heterozygotes, and they were selected so that their weight was as close as possible to that of their diabeticobese littermate. Each mouse was housed individually in a metal cage with a wiremesh floor. The cages were suspended $1 \mathrm{~cm}$ above absorbent paper so that food spillage could be readily collected and measured. The cages were placed in a ventilated, temperature-controlled cabinet of volume 7801 . The cabinets were maintained at either 23 or $33^{\circ} \mathrm{C}$. A $12 \mathrm{~h}$ light: $12 \mathrm{~h}$ dark cycle was operated in the cabinets in synchrony with the cycle of the main colony.

The lean mice were allowed to feed ad libitum, the diet used being Spillers-Spratts Rodent Breeding Diet 1 (Spratts Patent, Barking, Essex, U. K.) This diet contains $21.3 \%$ protein and $3.4 \%$ fat and $17.4 \mathrm{~kJ} / \mathrm{g}$. Tap water was freely available to all animals. The food intake of each lean mouse was determined daily between 0900 and $1030 \mathrm{~h}$, with a correction being made for spillage. This quantity of food was then given on the following day to the diabetic-obese partner.

In an attempt to reduce any effects of 'meal-feeding' the daily ration for the $\mathrm{db} / \mathrm{db}$ animals was given in two meals (see Discussion). The first meal was presented at approximately $1000 \mathrm{~h}$, and this amounted to one-third of the total ration. The remaining twothirds was given at approximately $1800 \mathrm{~h}$. Faeces were collected throughout the experimental period so that the digestible energy intake could be determined.

Pair-feeding was conducted for 14 days, a period which allowed an almost two-fold increase in the weight of the lean animals. A longer period was not used because of the need to minimise any secondary effects of the diabetic-obese state.

\section{Carcass Analysis}

Mice were killed by inhalation of diethyl ether, and stored at $-20^{\circ} \mathrm{C}$ until required for analysis.

The gut contents were removed from the carcasses which were then cut into small pieces and autoclaved at a pressure of $10^{4} \mathrm{~kg} / \mathrm{m}^{2}$ for $30 \mathrm{~min}$ [15]. The softened carcasses were homogenised in a small volume of water using a highspeed mixer (Silverson Machines, Chesham, Bucks, U. K.), and freeze-dried to constant weight.

The gross energy of the dried carcasses and the faeces was determined using a Gallenkamp Adiabatic Calorimeter (Model CB-100) which had been calibrated with dry benzoic acid (Gallenkamp, London, U. K.). Carcass nitrogen content was determined by a micro-Kjeldahl procedure using a Technicon Auto-Analyzer [18], and the protein content was derived by multiplying the nitrogen values $\times 6.25$. The accuracy of the nitrogen determination was approximately $1 \%$. Body fat was not measured in this study since with the smaller animals there was insufficient material remaining after the energy and nitrogen determinations. An estimate of fat content was made, however, by subtracting the energy as protein from the total carcass energy - assuming that this represented body fat. Values of $22.4 \mathrm{~kJ} / \mathrm{g}$ and $39.2 \mathrm{~kJ} / \mathrm{g}$ were taken for the energy content of protein and fat, respectively [8].

Carcass analysis was also performed on a group of 10 lean and 10 diabetic-obese mice of the same weight as the initial weight of the pair-fed animals.

\section{Statistical Analysis}

The statistical significance of differences between groups was assessed using Student's unpaired 't' test.

\section{Results}

\section{Initial Body Composition}

In order to determine the effects of pair-feeding on the body composition of the diabetic-obese mice it is necessary to have an estimate of their 'initial' composition. This was obtained by taking a reference group of lean and diabetic-obese animals which were similar in age and weight range to the experimental group at the beginning of the pair-feeding period. From the body composition of the reference animals a series of regression equations were obtained for each genotype of total energy, protein and estimated fat against weight. The equations, and the correlation coefficients observed for each of these parameters were:

energy content of lean $(\mathrm{kJ})=$

$12.3 \mathrm{~W}-53.0 \quad(\mathrm{r}=0.859)$.

energy content of diabetic-obese $(\mathrm{kJ})=$

$19.4 \mathrm{~W}-69.9(\mathrm{r}=0.904)$.

protein content of lean $(\mathrm{g})=$

$0.177 \mathrm{~W}-0.226(\mathrm{r}=0.932)$.

protein content of diabetic-obese $(\mathrm{g})=$

$0.058 \mathrm{~W}+0.805(\mathrm{r}=0.691)$.

fat content of lean $(\mathrm{g})=$

$$
0.213 \mathrm{~W}-1.232(\mathrm{r}=0.743) \text {. }
$$

fat content of diabetic-obese $(\mathrm{g})=$

$$
0.463 \mathrm{~W}-2.250(\mathrm{r}=0.874) \text {. }
$$

\section{Pair-feeding at $23^{\circ} \mathrm{C}$}

The results of the pair-feeding experiment conducted at an environmental temperature of $23^{\circ} \mathrm{C}$ are shown in Table 1. The starting weight of the lean and diabetic-obese animals was similar. There was no significant difference in the weight gain during pair-feeding, both groups showing an almost two-fold increase. The gross energy intake of the lean and diabetic-obese animals was the same, as was the digestibility of the dietary energy and therefore the digestible energy intake.

The initial energy content of the diabetic-obese mice was $75 \%$ higher than that of the lean. During pair-feeding the diabetic-obese gained $50 \%$ more energy than the lean, and their gross efficiency was elevated by a similar amount. The energy density of the weight gain was considerably lower in the lean animals than in the diabetic-obese. The mutant animals had an estimated initial fat content which was 
Table 1. Weight, energy, protein and fat gains of diabetic-obese mice, pair-fed to the ad libitum food intake of lean siblings at $23^{\circ} \mathrm{C}$

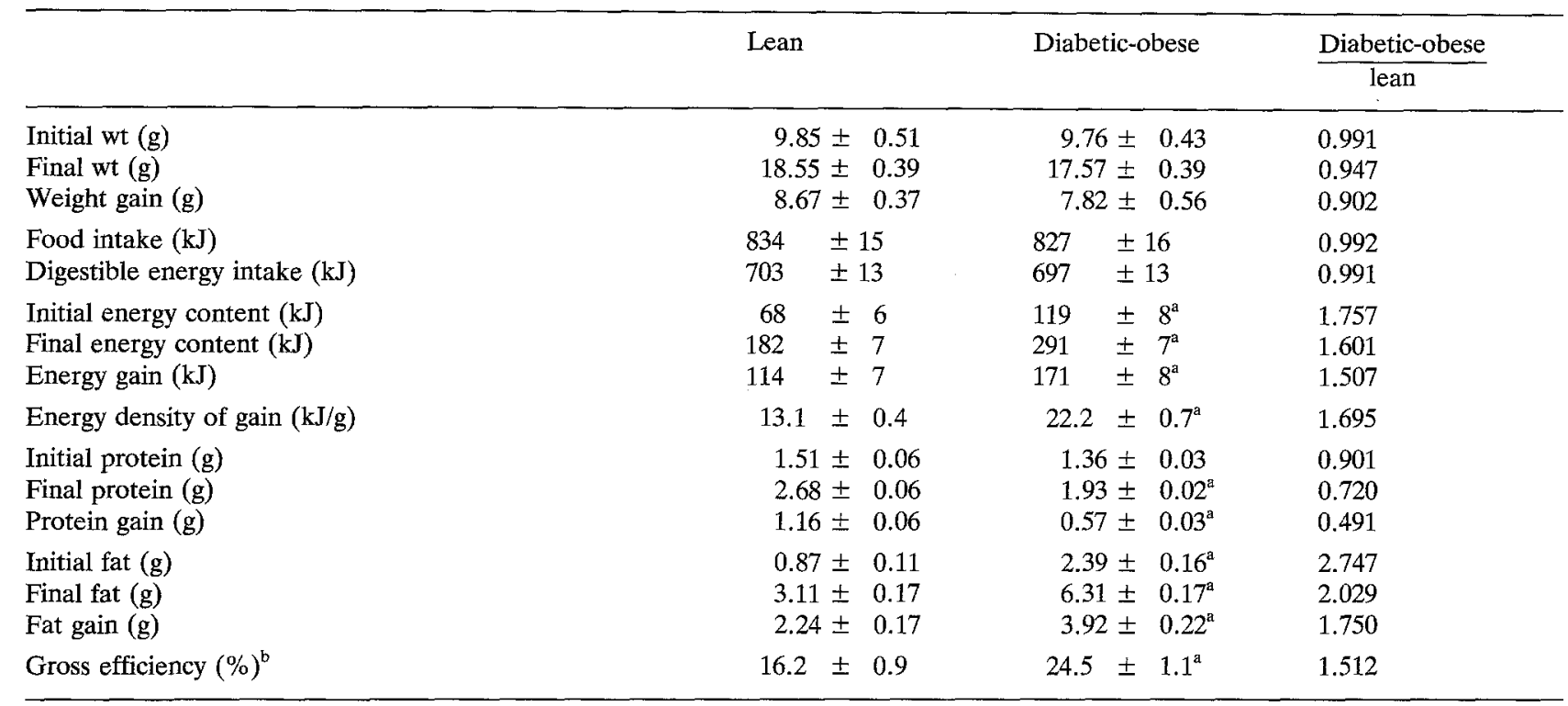

The results are mean values \pm SEM for 8 lean and 8 diabetic-obese animals. ${ }^{a} p<0.001$

The initial energy, protein and fat contents were estimated from the analyses obtained on the reference group of animals

${ }^{\mathrm{b}}$ Gross efficiency $=$ energy gain divided by digestible energy intake

Table 2. Weight, energy, protein and fat gains of diabetic-obese mice pair-fed to the ad libitum food intake of lean siblings at $33^{\circ} \mathrm{C}$

\begin{tabular}{|c|c|c|c|}
\hline & Lean & Diabetic-obese & $\frac{\text { Diabetic-obese }}{\text { lean }}$ \\
\hline Initial wt (g) & $8.93 \pm 0.27$ & $9.01 \pm 0.40$ & 1.009 \\
\hline Final wt $(\mathrm{g})$ & $16.34 \pm 0.49$ & $15.32 \pm 0.63^{\mathrm{b}}$ & 0.938 \\
\hline Weight gain $(\mathrm{g})$ & $7.41 \pm 0.33$ & $6.31 \pm 0.44^{b}$ & 0.852 \\
\hline Food intake $(\mathrm{kJ})$ & $480 \pm 19$ & $479 \pm 18$ & 0.998 \\
\hline Digestible energy intake $(\mathrm{kJ})$ & \pm 18 & \pm 15 & 0.990 \\
\hline Initial energy content $(\mathrm{kJ})$ & \pm 3 & $105 \pm 8^{\mathrm{c}}$ & 1.855 \\
\hline Final energy content $(\mathrm{kJ})$ & $170 \pm 8$ & $\pm 11^{\mathrm{c}}$ & 1.359 \\
\hline Energy gain $(\mathrm{kJ})$ & $114 \pm 6$ & \pm 7 & 1.113 \\
\hline Energy density of gain $(\mathrm{kJ} / \mathrm{g})$ & $15.3 \pm 0.3$ & $20.2 \pm 0.6^{\mathrm{c}}$ & 1.320 \\
\hline Initial protein $(\mathrm{g})$ & $1.35 \pm 0.06$ & $1.33 \pm 0.03$ & 0.985 \\
\hline Final protein $(\mathrm{g})$ & $2.24 \pm 0.06$ & $1.76 \pm 0.06^{c}$ & 0.786 \\
\hline Protein gain (g) & $0.89 \pm 0.03$ & $0.43 \pm 0.03^{\mathrm{c}}$ & 0.483 \\
\hline Initial fat $(\mathrm{g})$ & $0.67 \pm 0.06$ & $1.92 \pm 0.19^{c}$ & 2.866 \\
\hline Final fat $(\mathrm{g})$ & $3.07 \pm 0.17$ & $4.90 \pm 0.27^{c}$ & 1.596 \\
\hline Fat gain $(\mathrm{g})$ & $2.40 \pm 0.15$ & $2.99 \pm 0.20^{c}$ & 1.246 \\
\hline Gross efficiency $(\%)^{d}$ & $27.9 \pm 1.0$ & $31.4 \pm 1.6^{\mathrm{a}}$ & 1.125 \\
\hline
\end{tabular}

The results are mean values \pm SEM for 8 lean and 8 diabetic-obese animals. ${ }^{a}<0.05,{ }^{b} p<0.01,{ }^{c} p<0.001$

The initial energy, protein and fat contents were estimated from the analyses obtained on the reference group of animals

${ }^{\mathrm{d}}$ Gross efficiency $=$ energy gain divided by digestible energy intake

nearly three times greater than lean mice, and during the experimental period their gain in fat was $75 \%$ higher than in the lean.

The initial body protein content was slightly, but not significantly, higher in the lean animals than the mutants, but pair-feeding greatly inhibited protein deposition in the latter.

\section{Pair-feeding at $33^{\circ} \mathrm{C}$}

The results obtained when pair-feeding was conducted at $33^{\circ} \mathrm{C}$ are shown in Table 2 . The quantitative differences seen between lean and diabetic-obese animals in the initial energy, protein and fat contents were similar to those observed in the experiment per- 
formed at $23^{\circ} \mathrm{C}$. Successful pair-feeding was again achieved. The gross energy intake and the digestible energy intake were the same in the two groups. The digestibility of the diet was the same at $33^{\circ} \mathrm{C}$ as at $23^{\circ} \mathrm{C}$. Environmental temperature did affect the gross energy intake, however, for at $33^{\circ} \mathrm{C}$ it was only $58 \%$ of that observed at $23^{\circ} \mathrm{C}$.

Pair-feeding at $33^{\circ} \mathrm{C}$ resulted in a higher fat gain $(25 \%)$ in the diabetic-obese mice than in the lean, but the gain in protein was lower by one-half. The net effect of these changes was that overall the total energy gain of the diabetic-obese mutants was not significantly different from that of the normal animals.

\section{Discussion}

The pair-feeding experiment conducted at $23^{\circ} \mathrm{C}-\mathrm{a}$ normal temperature for housing mice - clearly shows that the diabetic-obese $(\mathrm{db} / \mathrm{db})$ mutant is more efficient than its lean siblings in that a greater proportion of dietary energy is retained (Table 1). This higher efficiency reflects the greater deposition of body fat in the diabetic-obese animal. The conclusion that obesity can develop in the $\mathrm{db} / \mathrm{db}$ mouse in the absence of hyperphagia is in agreement with previous results $[4,7]$.

In the present experiments, unlike the previous studies, the total energy gain of the lean and diabeticobese animals was measured directly. At $23^{\circ} \mathrm{C}$ the mutants deposited $51 \%$ more energy than the normal mice. This is much lower than the $320-430 \%$ increase which can be calculated from the experiments of Cox and Powley [7] on the $\mathrm{db} / \mathrm{db}$ mutant (assuming energy values of $39.2 \mathrm{~kJ} / \mathrm{g}$ for fat and $20.4 \mathrm{~kJ} / \mathrm{g}$ for 'fat-free solids'). The environmental temperature in the two studies was the same, but there are three other possible explanations for the different findings. In the present experiments pair-feeding was conducted for two weeks during the rapid phase of growth, whereas Cox and Powley [7] used a period of six weeks, and it is evident from the growth curves which they presented that during the second half of the experiment the lean controls were effectively at weight maintenance. Thus the lean animals must have deposited little or no energy for three weeks while energy deposition was still occurring in the diabetic-obese. The second explanation relates to their use of mice which were homozygous-normal (with respect to the $\mathrm{db}$ genotype) as lean controls while we used heterozygotes; there is some evidence that heterozygotes may have a higher efficiency than the homozygous-normal animals [5]. Heterozygotes were used as the lean controls in the present experi- (a)

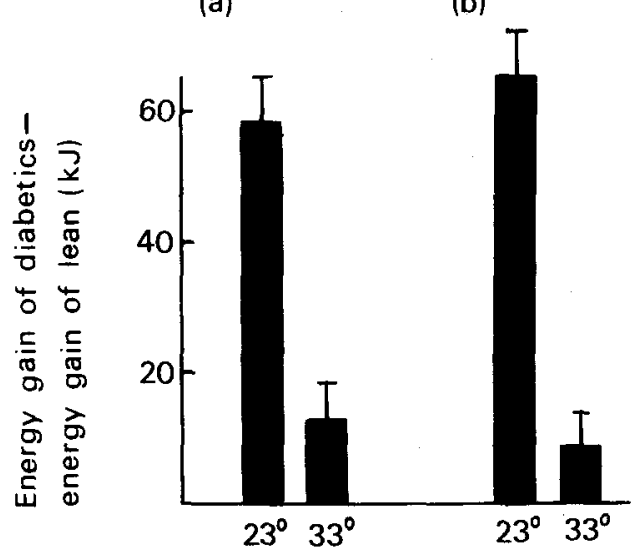

Fig. 1. The effect of environmental temperature $\left({ }^{\circ} \mathrm{C}\right)$ on the 'excess' energy gain of diabetic-obese mice pair-fed to the adlibitum food intake of lean siblings. (a) observed (b) adjusted for the presumed heat lost in growth; the adjustment is based on the assumption that the energy costs of fat and protein deposition are the same for lean and diabetic-obese animals, and that each $\mathrm{kJ}$ fat deposited costs $0.36 \mathrm{~kJ}$ and each $\mathrm{kJ}$ protein $1.25 \mathrm{~kJ}$ (see [18])

ments because of the difficulty in obtaining sexmatched homozygous-normal and diabetic-obese animals from the same litter. The third explanation is that Cox and Powley [7] used the $\mathrm{db}$ gene on a C57BL/6J background while the animals used in our experiments were the $\mathrm{C} 57 \mathrm{BL} / \mathrm{ks}$ strain. Since the diabetic syndrome induced by the $\mathrm{db}$ mutation is more severe on the latter background [4] the energy lost as glucose in the urine is likely to be greater than with the C57BL/6J strain. In consequence, with the $\mathrm{C} 57 \mathrm{BL} / \mathrm{ks}$ mice less of the digestible energy intake may be available to deposit as fat.

The pair-feeding system employed in the present study allowed the diabetic-obese animals the opportunity to "meal-feed". An attempt was made to minimise this by presenting the food in two meals each day, since the effects of meal-feeding in raising the efficiency of animals are well recognised [10]. However, Cox and Powley [7] found that by giving $\mathrm{db} / \mathrm{db}$ mice their food in one meal per day, efficiency was reduced rather than increased in comparison to animals which did not meal-feed. Meal-feeding is therefore unlikely to be a significant factor in the elevated efficiency reported here for $\mathrm{db} / \mathrm{db}$ mice.

It is noteworthy that in the present study the energy gain of the lean mice fed ad libitum was identical at $23^{\circ}$ and $33^{\circ} \mathrm{C}$. This observation is in contrast to the results obtained in previous studies where energy gain was observed to be greater in mice housed at thermoneutrality than at normal temperatures $[17,18]$. Strain differences are likely to account for this discrepancy. 
The primary aim of the present study was to determine whether a reduced energy expenditure on thermoregulatory thermogenesis (in practise nonshivering thermogenesis) was an important factor in the high efficiency of the $\mathrm{db} / \mathrm{db}$ mouse. Both body temperature $[20,23]$ and metabolic rate measurements [20] had suggested that this was likely to be the case. In order to make a quantitative nutritional assessment of the importance of reduced thermoregulatory thermogenesis to energy balance pairfeeding experiments were conducted at thermoneutrality $\left(33^{\circ} \mathrm{C}\right)$ where, contrary to studies at lower temperatures, there is no requirement for thermoregulatory heat. At thermoneutrality, the energy gain of the diabetic-obese mice was only slightly, but not significantly, greater than that of the lean animals to which they were paired (Table 2).

The effect of environmental temperature $\left(23^{\circ}\right.$ and $33^{\circ} \mathrm{C}$ ) on the difference in energy gain between lean and diabetic-obese animals (i. e. energy gain of mutants minus energy gain of controls) is shown in Figure 1. By conducting the pair-feeding at thermoneutrality, and therefore removing what is a major component of energy expenditure at normal temperatures, $78 \%$ of the extra energy gained by the mutants over the lean animals at $23^{\circ} \mathrm{C}$ is removed (Fig. 1a). This value rises to $87 \%$ when the differing energy costs of growth are taken into account (Fig. 1b); this adjustment has been made since on the one hand the greater fat deposition of the diabeticobese animals involves an increased energy expenditure, while on the other hand their lower protein deposition results in a reduced expenditure.

It is interesting to note that at both $23^{\circ}$ and $33^{\circ} \mathrm{C}$ the pair-fed diabetic-obese mice deposit only half as much protein as their lean siblings (Tables 1 and 2). Thus, even at thermoneutrality, there is a positive discrimination against the deposition of protein in favour of fat storage. The reasons for such a discrimination, which also occurs in the ob/ob mutant [18], are not clear. Although protein turnover has been implicated in the reduced thermogenesis of the ob/ob mouse [16], it now appears that almost all of the decreased energy expenditure on thermogenesis in this mutant can be attributed to the mitochondrial proton conductance pathway in brown adipose tissue $[12,19]$ - and this is likely to also apply to the diabetic-obese mouse.

In conclusion, the present experiments together with the earlier metabolic rate measurements [20], clearly indicate that the low energy expenditure and consequent high metabolic efficiency of the diabeticobese mutant is due to reduced thermoregulatory thermogenesis. This is also the mechanism by which the obese (ob/ob) mouse achieves its high efficiency
$[18,21,22]$. This similarity has prompted the suggestion that a reduction in thermoregulatory, or nonshivering, thermogenesis is the general mechanism through which the "thrifty" genotype associated with diabetes-obesity may operate [20].

Acknowledgement. We are grateful to Drs. W. P. T. James, P. L. Thurlby and D. R. Fraser for their helpful comments.

\section{References}

1. Alonso LG, Maren TH (1955) Effect of food restriction on body composition of hereditary obese mice. Am J Physiol 183: 284-290

2. Bray GA, York DA (1979) Hypothalamic and genetic obesity in experimental animals: an autonomic and endocrine hypothesis. Physiol Rev 59: 719-809

3. Chlouverakis C (1970) Induction of obesity in obese-hyperglycaemic mice on normal food intake. Experientia 26: 1262-1263

4. Coleman DL (1978) Obese and diabetes: Two mutant genes causing diabetes-obesity syndromes in mice. Diabetologia 14: 141-148

5. Coleman DL (1979) Obesity genes: beneficial effects in heterozygous mice. Science 203: 663-665

6. Coleman DL, Hummel KP (1974) Hyperinsulinemia in preweaning diabetes $(\mathrm{db})$ mice. Diabetologia 10: 607-610

7. Cox JE, Powley TL (1977) Development of obesity in diabetic mice pair-fed with lean siblings. J Comp Physiol Psychol 91 347-358

8. Davidson S, Passmore R, Brock JF, Truswell AS (1975) Human nutrition and dietetics, sixth ed. Churchill Livingstone, Edinburgh London New York, p 19

9. Dubuc PU (1976) Effects of limited food intake on the obesehyperglycemia syndrome Am J Physiol 230: 1474-1479

10. Fábry $\mathbf{P}(1969)$ Feeding patterns and nutritional adaptations. Butterworth, London

11. Herberg L, Coleman DL (1977) Laboratory animals exhibiting obesity and diabetes syndromes. Metabolism 26: 59-98

12. Himms-Hagen J, Desautels M (1978) A mitochondrial defect in brown adipose tissue of the obese (ob/ob) mouse: reduced binding of purine nucleotides and a failure to respond to cold by an increase in binding. Biochem Biophys Res Commun 83: 628-634

13. Hummel KP, Dickie MM, Coleman DL (1966) Diabetes, a new mutation in the mouse. Science 153: 1127-1128

14. Le Marchand-Brustel Y, Jeanrenaud B (1978) Pre- and post weaning studies on development of obesity in $\mathrm{mdb} / \mathrm{mdb}$ mice. Am J Physiol 234: E568-574

15. Lofti M, Macdonald IA, Stock MJ (1976) Energy losses associated with oven-drying and the preparation of rat carcasses for analysis. Br J Nutr 36: 305-309

16. Miller BG, Otto WR, Grimble RF, York DA, Taylor TG (1979) The relationship between protein turnover and energy balance in lean and genetically obese (ob/ob) mice. Br. J Nutr 42: 185-199

17. Stanier MW (1977) Effect of environmental temperature and food intake on the distribution of fat in growing hairless mice. Br J Nutr 37: 279-284

18. Thurlby PL, Trayhurn P (1979) The role of thermoregulatory thermogenesis in the development of obesity in genetically obese (ob/ob) mice pairfed with lean siblings. Br J Nutr 42: $377-385$ 
19. Thurlby PL, Trayhurn $\mathbf{P}$ (in press) Regional blood flow in genetically obese (ob/ob) mice: the importance of brown adipose tissue to the reduced energy expenditure on non-shivering thermogenesis. Pflügers Arch

20. Trayhurn $P$ (1979) Thermoregulation in the diabetic-obese $(\mathrm{db} / \mathrm{db})$ mouse: the role of non-shivering thermogenesis in energy balance. Pflügers Arch 380: 227-232

21. Trayhurn P, James WPT (1978) Thermoregulation and nonshivering thermogenesis in the genetically obese (ob/ob) mouse. Pflügers Arch 373: 189-193

22. Trayhurn P, Thurlby PL, Woodward CJH, James WPT (1979) Thermoregulation in genetically obese rodents: the relationship to metabolic efficiency. In: Festing MFW (ed) Animal models of obesity. Macmillans, London, p 191-203

23. Yen TT, Fuller RW, Pearson DV (1974) The response of "obese" (ob/ob) and "diabetic" ( $\mathrm{db} / \mathrm{db})$ mice to treatments that influence body temperature. Comp Biochem Physiol 49 [A]: $377-385$

24. Zucker LM (1975) Efficiency of energy utilization by the Zucker herditarily obese rat "fatty". Proc Soc Exp Biol Med 148: $498-500$

Received: October 15,1979 ,

and in revised form: March 24, 1980

Dr. P. Trayhurn

Dunn Nutrition Laboratory

University of Cambridge and Medical Research Council

Milton Road

Cambridge CB4 1 XJ

England 